\title{
Perlindungan Hak Cipta Film Terhadap Kegiatan Streaming Pada Situs Web IndoXX1
}

\author{
Ganisha Fiebelina Yudianto \\ Program Studi Magister Hukum, Fakultas Hukum Universitas Indonesia \\ Email: ganishafy@gmail.com
}

\begin{abstract}
Abstrak. Pelanggaran Hak Cipta menjadi salah satu dampak negatif kemajuan teknologi dan informasi. Salah satunya adalah pelanggaran Hak Cipta film yang dilakukan oleh penyedia situs layanan streaming film gratis yaitu situs web IndoXX1. Pelanggaran tersebut menimbulkan permasalahan bagaimana pengaturan Hak Cipta film terhadap kegiatan streaming film gratis pada situs web IndoXX1 berdasarkan Pasal 55 ayat (1) Undang-Undang Hak Cipta? dan bagaimana upaya Direktorat Jenderal Kekayaan Intelektual dalam melindungi karya film terhadap kegiatan streaming film gratis pada situs web IndoXX1?. Penelitian dilakukan secara normatif bersifat deskriptif, menggunakan data sekunder dianalisis secara kualitatif, serta penarikan kesimpulan menggunakan logika deduktif. Hasil penelitian menggambarkan bahwa (1) Pengaturan Hak Cipta film terhadap kegiatan streaming film gratis pada situs web IndoXX1 terdapat dalam Pasal 55 ayat (1) UndangUndang Hak Cipta yaitu penutupan situs serta dalam Pasal 99 ayat (3) huruf b Undang-Undang Hak Cipta selanjutnya ketentuan pidana juga diatur dalam Pasal 113 ayat (2) dan ayat (3) Undang-Undang Hak Cipta; (2) Seluruh upaya untuk memberikan perlindungan Hak Cipta film bergantung kepada peran aktif pencipta karya film untuk melaporkan pelanggaran Hak Cipta karena yang berlaku adalah delik aduan baik itu upaya perdata maupun upaya pidana. Sehingga Direktorat Jenderal Kekayaan Intelektual tidak dapat memberikan perlindungan Hak Cipta film apabila tidak ada laporan.
\end{abstract}

Kata Kunci: Hak Cipta, Perlindungan, Film, Streaming, Internet

\section{PENDAHULUAN}

\section{Latar Belakang}

Kemajuan teknologi informasi membawa manfaat positif salah satunya adalah dengan mempermudah kehidupan sehari-hari, seperti dalam pembelajaran hingga hal-hal kecil terdapat dalam internet. Seiring dengan perkembangan zaman era global dan dengan kemajuan teknologi informasi, kini untuk menyaksikan film kita hanya perlu mengakses situs web yang menyediakan layanan film secara streaming sudah bisa mendapatkan hiburan dengan menyaksikan film yang ingin disaksikan. Salah satu situs web yang menyediakan layanan streaming film gratis adalah situs web IndoXX1. Film adalah karya seni budaya yang merupakan pranata sosial dan media komunikasi massa yang dibuat berdasarkan kaidah sinematografi dengan atau tanpa suara dan dapat dipertunjukkan.

Dalam pembuatan suatu film, pencipta suatu karya film harus menuangkan ide cerita film ke dalam bentuk nyata hingga terciptalah suatu karya film. Dari hal tersebut dapat diketahui bahwa untuk membuat suatu film produser film harus menunjang pembuatan suatu film dengan memberi modal. Modal tersebut terdiri atas berbagai aspek, dari sumber daya alam, sumber daya manusia, hingga pendanaan. Melihat hal tersebut sudah seharusnya negara khususnya Direktorat Jenderal Kekayaan Intelektual memberikan perlindungan atas Hak Cipta suatu Ciptaan terutama dalam hal ini karya film. Perlindungan tersebut dapat berupa pengaturan dalam bentuk peraturan perundang-undangan yang mengatur secara jelas dan tegas mengenai perlindungan hukum atas suatu karya cipta dalam media teknologi informasi dan pelaksanaannya harus diterapkan secara tegas dan konsisten. Undang-Undang Hak Cipta telah mengatur mengenai perlindungan Hak Cipta terhadap karya film tepatnya diatur dalam Pasal 40 ayat (1) huruf m UndangUndang Nomor 28 Tahun 2014 tentang Hak Cipta yang mengatur bahwa karya sinematografi termasuk ke dalam ciptaan yang dilindungi oleh Undang-Undang Hak Cipta. 
Kegiatan streaming film gratis dapat menimbulkan kerugian bagi pemegang Hak Cipta film tersebut, karena pengguna dengan melakukan kegiatan streaming film gratis tanpa seizin pemegang Hak Cipta tidak perlu membayar sebagaimana apabila kita menyaksikan film di bioskop yang mewajibkan kita membayar untuk suatu tiket yang dipergunakan sebagai alat untuk menyaksikan film di bioskop. Jadi apabila dalam situs web yang tidak berbayar dan ilegal seperti situs web IndoXX1, pemegang Hak Cipta tidak mendapatkan manfaat ekonomi berupa royalti atas pengumuman serta penyebaran Ciptaan tersebut.

Saat ini masyarakat masih belum menganggap kegiatan streaming film gratis di situs web adalah suatu hal yang serius karena ada hak orang lain yang telah terlanggar yaitu pemegang Hak Cipta. Hal tersebut dibuktikan dengan masih banyak pengguna yang melakukan akses ke situs web IndoXX1 dan menikmati situs web IndoXX1 tanpa menyadari hak-hak pemegang Hak Cipta atas karya film yang terdapat dalam situs web tersebut. Padahal dengan masyarakat masih menggunakan situs penyedia jasa layanan streaming gratis ilegal seperti situs web IndoXX1 jelas masyarakat telah menyalahi Undang-Undang Hak Cipta karena memang perbuatan tersebut tergolong pelanggaran Hak Cipta walaupun memang tidak akan mendapatkan sanksi. Sedangkan pihak situs web IndoXX1 jelas dapat dikenakan sanksi dan dimintai pertanggungjawaban karena telah melanggar Pasal 9 ayat (1) huruf e, g, dan h Undang-Undang Hak Cipta yaitu dengan mendistribusikan, mengumumkan dan mengkomunikasikan suatu karya film kepada publik tanpa seizin pencipta atau pemegang Hak Cipta karya film tersebut untuk penggunaan secara komersial.

Pelanggaran Hak Cipta seperti kegiatan streaming film gratis pada situs web IndoXX1 tergolong pelanggaran Hak Cipta melalui sistem elektronik atau media teknologi informasi. Dalam Pasal 55 ayat (1) UndangUndang Nomor 28 Tahun 2014 tentang Hak Cipta diatur bahwa, "Setiap Orang yang mengetahui pelanggaran Hak Cipta dan/atau
Hak Terkait melalui sistem elektronik untuk Penggunaan Secara Komersial dapat melaporkan kepada Menteri." Dalam penerapan Pasal 55 Undang-Undang Hak Cipta tersebut maka pencipta atau pemegang Hak Cipta harus berperan aktif dalam melaporkan adanya pelanggaran Hak Cipta terhadap karya ciptanya kepada Direktorat Jenderal Kekayaan Intelektual yang berada dibawah naungan Kementerian Hukum dan Hak Asasi Manusia Republik Indonesia. Hal tersebut dilatarbelakangi oleh berlakunya delik aduan dalam Pasal 55 Undang-Undang Hak Cipta tersebut sehingga Direktorat Jenderal Kekayaan Intelektual tidak mungkin memberikan perlindungan dalam bentuk penutupan situs apabila tidak didahului dengan adanya laporan dari pihak yang dilanggar Hak Ciptanya. Berdasarkan uraian yang telah diuraikan di atas, maka penulis melakukan penelitian mengenai "Perlindungan Hak Cipta Film Terhadap Kegiatan Streaming Film Gratis Pada Situs Web IndoXX1 Berdasarkan Undang-Undang Republik Indonesia Nomor 28 Tahun 2014 tentang Hak Cipta."

\section{Pokok Permasalahan}

Berdasarkan pada latar belakang yang telah diuraikan sebelumnya maka dalam penelitian ini akan dikemukakan beberapa rumusan masalah sebagai berikut:

1. Bagaimana pengaturan Hak Cipta film terhadap kegiatan streaming film gratis pada situs web IndoXX1 berdasarkan penerapan pelaporan pelanggaran Hak Cipta sebagaimana diatur dalam Pasal 55 ayat (1) Undang-Undang Nomor 28 Tahun 2014 tentang Hak Cipta?

2. Bagaimana upaya Direktorat Jenderal Kekayaan Intelektual dalam melindungi karya film terhadap kegiatan streaming film gratis pada situs web IndoXX1?

\section{METODE PENELITIAN}

\section{Tipe Penelitian}

Penelitian mengenai "Perlindungan Hak Cipta Film Terhadap Kegiatan Streaming Film Gratis Pada Situs Web IndoXX1 Berdasarkan Undang-Undang Republik Indonesia Nomor 28 Tahun 2014 tentang Hak Cipta" merupakan 
suatu penelitian hukum normatif, dimana metode penelitian hukum normatif adalah metode penelitian hukum yang digunakan dengan cara meneliti bahan pustaka yang ada. Dengan dikategorikannya sebagai penelitian hukum normatif, maka penelitian ini merupakan penelitian terhadap azas-azas hukum karena penelitian ini didasarkan pada analisa norma hukum dan peraturan perundang-undangan yang berlaku serta untuk mendapatkan azas-azas hukum dari hukum positif tertulis maupun tidak tertulis. Walaupun penelitian yang digunakan adalah penelitian normatif yaitu penelitian yang hanya menggunakan bahan pustaka yang ada, tetapi dalam penelitian ini penulis juga menggunakan data yang diperoleh dari kegiatan wawancara sebagai data pelengkap bukan sebagai data pokok.

\section{Sifat Penelitian}

Sifat penelitian yang digunakan penulis dalam penelitian ini adalah penelitian hukum bersifat deskriptif yang menggambarkan suatu keadaan atau peristiwa yang terjadi saat ini secara sistematis. Sesuai dengan penelitian ini yaitu menggambarkan penerapan pelaporan pelanggaran hak cipta yang diatur dalam Pasal 55 ayat (1) Undang-Undang Nomor 28 Tahun 2014 tentang Hak Cipta untuk mengatasi kegiatan streaming film gratis pada situs web IndoXX1 dan upaya Direktorat Jenderal Kekayaan Intelektual dalam melindungi karya film terhadap kegiatan streaming film gratis pada situs web IndoXX1.

\section{Data dan Sumber Data}

Berdasarkan tipe penelitian yang digunakan dalam penelitian ini yaitu penelitian normatif maka dapat disimpulkan bahwa sumber data yang digunakan adalah data sekunder. Data sekunder adalah data yang mencakup dokumen-dokumen resmi, bukubuku, hasil-hasil penelitian yang berwujud laporan.

Data sekunder yang digunakan dalam penelitian ini adalah bahan hukum primer, bahan hukum sekunder dan bahan hukum tersier. Bahan hukum primer yang digunakan adalah Undang-Undang Nomor 28 Tahun 2014 tentang Hak Cipta, Peraturan Bersama Menteri Hukum dan Hak Asasi Manusia
Republik Indonesia dan Menteri Komunikasi dan Informatika Republik Indonesia Nomor 14 Tahun 2015 dan Nomor 26 Tahun 2015 tentang Pelaksanaan Penutupan Konten dan/atau Hak Akses Pengguna Pelanggaran Hak Cipta dan/atau Hak Terkait dalam Sistem Elektronik, Undang-Undang Nomor 19 Tahun 2016 tentang Perubahan Atas Undang-Undang Nomor 11 Tahun 2008 tentang Informasi dan Transaksi Elektronik dan Undang-Undang Nomor 33 Tahun 2009 tentang perfilman sebagai referensi tambahan untuk definisi dan sumber informasi lainnya, lalu bahan hukum sekunder yang digunakan adalah buku, jurnal maupun makalah ilmiah online mengenai perlindungan Hak Cipta atas karya film dan Hak Cipta pada umumnya, kemudian bahan hukum tersier yang digunakan adalah Kamus Besar Bahasa Indonesia (KBBI).

Sedangkan data primer yang digunakan dalam penelitian ini diperoleh secara langsung dari sumber aslinya melalui proses wawancara. Tetapi dalam penelitian ini penggunaan data primer bukan sebagai data pokok melainkan hanya sebagai data pelengkap untuk melengkapi dan memperkuat data sekunder. Pihak yang menjadi narasumber adalah Kepala Sub Direktorat Pelayanan Hukum Direktorat Hak Cipta dan Desain Industri Direktorat Jenderal Kekayaan Intelektual Republik Indonesia yaitu Agung Damarsasongko, S.H., M.H. dan Afif Nurachman dari Sub Direktorat Pengendalian Konten Internet Direktorat Pengendalian Aplikasi Informatika Kementerian Komunikasi dan Informatika Republik Indonesia.

\section{Pengumpulan Data}

Dalam penelitian ini pengumpulan data primer sebagai data pelengkap dilakukan melalui kegiatan wawancara kepada beberapa narasumber dan pengumpulan data sekunder dilakukan melalui studi kepustakaan. Studi kepustakaan dilakukan di beberapa tempat seperti perpustakaan Fakultas Hukum Universitas Trisakti dan perpustakaan Fakultas Hukum Universitas Indonesia. Pengumpulan data primer melalui wawancara dilakukan terhadap narasumber dari Direktorat Jenderal Kekayaan Intelektual Republik Indonesia dan 
Kementerian Komunikasi dan Informatika Republik Indonesia.

\section{Analisis Data}

Data yang telah diperoleh selanjutnya akan dianalisis secara kualitatif, artinya data yang telah didapat disusun secara sistematis dalam bentuk uraian atau penjelasan untuk menggambarkan hasil penelitian sehingga mudah dipahami agar dapat diinformasikan kepada orang lain. Pada penelitian ini dilakukan analisis terhadap Undang-Undang Nomor 28 Tahun 2014 tentang Hak Cipta, Peraturan Bersama Menteri Hukum dan Hak Asasi Manusia Republik Indonesia dan Menteri Komunikasi dan Informatika Republik Indonesia Nomor 14 Tahun 2015 dan Nomor 26 Tahun 2015 tentang Pelaksanaan Penutupan Konten dan/atau Hak Akses Pengguna Pelanggaran Hak Cipta dan/atau Hak Terkait dalam Sistem Elektronik, Undang-Undang Nomor 19 Tahun 2016 tentang Perubahan Atas Undang-Undang Nomor 11 Tahun 2008 tentang Informasi dan Transaksi Elektronik dan Undang-Undang Nomor 33 Tahun 2009 tentang perfilman serta beberapa literatur atau buku yang berkaitan dengan objek penelitian, dalam permasalahan pelanggaran Hak Cipta karya film terhadap kegiatan streaming film gratis pada suatu situs web.

\section{Cara Penarikan Kesimpulan}

Dalam penelitian ini penarikan kesimpulan dilakukan dengan menggunakan logika deduktif, artinya metode menarik kesimpulan yang menerapkan hal-hal yang umum terlebih dahulu untuk kemudian di hubungkan dengan bagian-bagian yang khusus atau di implementasikan kebagian yang khusus. Pada metode ini, penarikan kesimpulan dilakukan dengan menganalisis konsep-konsep umum Hak Kekayaan Intelektual khususnya mengenai pengaturan Hak Cipta dalam Undang-Undang Nomor 28 Tahun 2014 tentang Hak Cipta, kemudian konsep yang bersifat umum tersebut akan dianalisis secara khusus dalam perlindungan Hak Cipta film terhadap kegiatan streaming film gratis pada situs web IndoXX1 berdasarkan penerapan pelaporan pelanggaran Hak Cipta dan upaya Direktorat Jenderal
Kekayaan Intelektual dalam melindungi suatu karya film dari kegiatan streaming film gratis pada situs web IndoXX1.

\section{ANALISIS PERLINDUNGAN HAK CIPTA FILM TERHADAP KEGIATAN STREAMING FILM GRATIS PADA SITUS WEB INDOXX1}

1. Pengaturan Hak Cipta Film Terhadap Kegiatan Streaming Film Gratis Pada Situs Web IndoXX1 Berdasarkan Penerapan Pelaporan Pelanggaran Hak Cipta dalam Pasal 55 Ayat (1) UndangUndang Nomor 28 Tahun 2014 tentang Hak Cipta

Perlindungan yang diberikan oleh Undang-Undang Hak Cipta terhadap karya film diatur dalam Pasal 40 ayat (1) huruf $\mathrm{m}$ Undang-Undang Nomor 28 Tahun 2014 tentang Hak Cipta dimana film yang merupakan karya sinematografi termasuk ke dalam ciptaan yang dilindungi oleh UndangUndang Hak Cipta. Selanjutnya sebagai tindak lanjut dari pengaturan perlindungan Hak Cipta karya film yang terdapat dalam Pasal 40 ayat (1) huruf m Undang-Undang Hak Cipta, dalam melindungi Hak Cipta karya film terhadap pelanggaran Hak Cipta melalui sistem elektronik untuk penggunaan secara komersial seperti pelanggaran yang dilakukan oleh situs web IndoXX1 maka dalam Undang-Undang Hak Cipta juga diatur mengenai hal tersebut sebagai upaya menanggulangi pelanggaran Hak Cipta melalui media teknologi dan informasi tepatnya dalam Pasal 55 ayat (1) Undang-Undang Nomor 28 Tahun 2014 tentang Hak Cipta. Dalam penerapan Pasal 55 ayat (1) Undang-Undang Hak Cipta terhadap pelanggaran Hak Cipta yang dilakukan oleh situs web IndoXX1 tersebut diawali dengan adanya laporan situs atau konten yang melanggar Hak Cipta dan atau Hak Terkait. Hal tersebut seperti yang dilakukan oleh Motion Picture Association (MPA) yang melaporkan 89 situs yang melakukan pelanggaran Hak Cipta atas karya film termasuk diantaranya MPA melaporkan situs web IndoXX1.

Langkah selanjutnya dalam penerapan Pasal 55 ayat (1) Undang-Undang Hak Cipta 
tersebut adalah Direktorat Jenderal Kekayaan Intelektual melakukan verifikasi atas laporan tersebut dengan membentuk tim verifikasi yang terdiri dari Direktorat Jenderal Kekayaan Intelektual khususnya Direktorat Hak Cipta dan Desain Industri, Kementerian Komunikasi dan Informatika Republik Indonesia khususnya Sub Direktorat Pengendalian Konten Internet, dan asosiasi terkait dengan Hak Cipta dan atau Hak Terkait. Dalam hal ini situs web IndoXX1 terbukti melakukan pelanggaran Hak Cipta maka pembuatan rekomendasi dilakukan berdasarkan hasil verifikasi bahwa ditemukan bukti bahwa situs web IndoXX1 tidak memiliki lisensi dari pencipta atau pemegang Hak Cipta film yang didistribusikannya serta tidak memberikan royalti kepada pencipta atau pemegang Hak Cipta film tersebut dan dianggap memenuhi unsur pelanggaran Hak Cipta. Rekomendasi tersebut berupa penutupan seluruh konten yang melanggar Hak Cipta dalam sistem elektronik. Penutupan secara keseluruhan selain karena situs web IndoXX1 melakukan pelanggaran Hak Cipta, dalam situs web IndoXX1 juga terdapat konten perjudian dan konten pornografi dimana hal tersebut melanggar UU ITE. Rekomendasi tersebut dengan disertai alasan disampaikan oleh Direktur Jenderal Kekayaan Intelektual atas nama Menteri Hukum dan Hak Asasi Manusia kepada Menteri Komunikasi dan Informatika Republik Indonesia melalui Direktur Jenderal Aplikasi Informatika. Atas rekomendasi tersebut maka Kementerian Komunikasi dan Informatika Republik Indonesia melalui Direktur Jenderal Aplikasi Informatika Sub Direktorat Pengendalian Konten Internet melakukan penutupan seluruh konten situs web IndoXX1 sehingga situs tersebut tidak dapat diakses.

Pasal dalam Undang-Undang Hak Cipta yang dilanggar oleh situs web IndoXX1 terkait dengan pelanggaran Hak Cipta yang dilakukannya adalah Pasal 9 ayat (1) huruf e, g dan h juncto Pasal 9 ayat (2) juncto Pasal 9 ayat (3) Undang-Undang Nomor 28 Tahun 2014 tentang Hak Cipta karena situs web IndoXX1 telah mendistribusikan dan mengumumkan karya cipta film melalui alat elektronik sehingga karya film tersebut dapat dilihat orang lain tanpa izin pencipta atau pemegang Hak Cipta karya film tersebut dan untuk penggunaan secara komersial.

Berdasarkan Pasal 99 Undang-Undang Hak Cipta bahwa, "Pencipta, Pemegang Hak Cipta, atau pemilik Hak Terkait berhak mengajukan gugatan ganti rugi kepada Pengadilan Niaga atas pelanggaran Hak Cipta atau produk Hak Terkait" maka pencipta atau pemegang Hak Cipta karya film dapat mengajukan gugatan ganti rugi kepada Pengadilan Niaga atas pelanggaran Hak Cipta film. Gugatan ganti rugi dapat berupa permintaan untuk menyerahkan seluruh atau sebagian penghasilan yang diperoleh pihak situs web IndoXX1 selama mengumumkan, mempertunjukan dan mengkomunikasikan karya film tanpa seizin pencipta atau pemegang Hak Cipta karya film tersebut dalam situs web IndoXX1. Selain daripada hal tersebut, gugatan keperdataan juga dapat dilakukan pencipta atau pemegang Hak Cipta dengan memohon putusan provisi atau putusan sela kepada Pengadilan Niaga untuk meminta penyitaan ciptaan yang dilakukan pengumuman atau penggandaan yaitu karya film atau untuk menghentikan kegiatan pengumuman, pendistribusian dan komunikasi karya film dalam situs web IndoXX1 atau dalam bentuk penutupan situs web IndoXX1. Hal tersebut diatur dalam Pasal 99 ayat (3) huruf a dan huruf b Undang-Undang Nomor 28 Tahun 2014 tentang Hak Cipta. Ketentuan pidana yang dapat dikenakan diatur dalam Pasal 113 ayat (2) juncto Pasal 113 ayat (3) Undang-Undang Nomor 28 Tahun 2014 tentang Hak Cipta. Hal tersebut dilatarbelakangi oleh pihak situs web IndoXX1 yang telah melanggar Pasal 9 ayat (1) huruf e, g, dan h Undang-Undang Hak Cipta seperti yang telah dijelaskan sebelumnya. Tetapi selama tidak ada laporan atau pengaduan akan terjadinya pekanggaran Hak Cipta maka ketentuan pidana tidak dapat dikenakan kepada pelanggar Hak Cipta dalam hal ini yaitu pihak situs web IndoXX1. Hal tersebut sesuai dengan ketentuan Pasal 120 Undang-Undang Nomor 28 Tahun 2014 tentang Hak Cipta bahwa tindak pidana dalam 
Undang-Undang Hak Cipta merupakan delik aduan. Sehingga peran aktif dari pencipta atau pemegang Hak Cipta untuk melaporkan adanya pelanggaran Hak Cipta terhadap ciptaannya juga sebagai bentuk perjuangan hukum untuk memberantas pelanggaran Hak Cipta di Indonesia. Apabila pencipta atau pemegang Hak Cipta tidak melaporkan pelanggaran Hak Cipta atas ciptaannya maka pelaku pelanggaran Hak Cipta dapat dengan leluasa melakukan pelanggaran Hak Cipta.

Berdasarkan hal yang telah diuraikan sebelumnya maka dapat disimpulkan bahwa ketentuan pidana memiliki kelemahan yaitu karena berlakunya delik aduan maka tanpa adanya laporan dari pencipta atau pemegang Hak Cipta ketentuan pidana tidak dapat dikenakan terhadap pelaku pelanggaran Hak Cipta. Apabila pencipta karya film tersebut berada di luar wilayah Negara Kesatuan Republik Indonesia tentu saja merupakan hal yang sulit untuk melakukan laporan atas pelanggaran Hak Cipta terhadap karya filmnya. Maka berdasarkan hal tersebut pengaturan perlindungan Hak Cipta dalam Undang-Undang Hak Cipta selain Pasal 55 Undang-Undang Hak Cipta yang mengatur mengenai penutupan situs selanjutnya pencipta atau pemegang Hak Cipta juga dapat menggunakan aturan dalam Pasal 99 mengenai gugatan keperdataan dan Pasal 113 yang mengatur mengenai ketentuan pidana.

\section{Upaya Direktorat Jenderal Kekayaan Intelektual Dalam Melindungi Karya Film Terhadap Kegiatan Streaming Film Gratis Pada Situs Web IndoXX1}

Direktorat Jenderal Kekayaan Intelektual berkoordinasi dengan Kementerian Komunikasi dan Informatika Republik Indonesia telah berulang kali melakukan upaya untuk melindungi karya film terhadap kegiatan streaming film gratis pada situs web IndoXX1 dengan melakukan penutupan terhadap situs web IndoXX1 berdasarkan laporan adanya pelanggaran Hak Cipta melalui sistem elektronik sebagaimana dimaksud dalam Pasal 55 ayat (1) Undang-Undang Nomor 28 Tahun 2014 tentang Hak Cipta. Namun pihak situs web IndoXX1 mengganti nama domain situs web IndoXX1 secara terus menerus terutama apabila setelah mengalami penutupan situs agar situs web IndoXX1 tetap dapat diakses oleh pengguna.

Terdapat 2 (dua) upaya yang dapat dilakukan pencipta atau pemegang Hak Cipta sebagai bentuk perjuangan hukum yaitu upaya melalui gugatan keperdataan dan upaya melalui tuntutan pidana. Berdasarkan Pasal 99 Undang-Undang Hak Cipta, gugatan keperdataan terbagi menjadi 2 (dua), yang pertama adalah pencipta atau pemegang Hak Cipta karya film dapat mengajukan gugatan ganti rugi kepada Pengadilan Niaga untuk meminta seluruh atau sebagian penghasilan yang diperoleh situs web IndoXX1 selama pengumuman dan komunikasi karya film tanpa izin yang tergolong sebagai pelanggaran Hak Cipta yang dilakukan oleh pihak situs web IndoXX1. Selain daripada mengajukan gugatan ganti rugi, gugatan keperdataan lainnya adalah pencipta atau pemegang Hak Cipta karya film dapat memohon putusan provisi atau putusan sela kepada Pengadilan Niaga untuk meminta penyitaan karya film yang dilakukan pengumuman secara ilegal dan/atau untuk menghentikan kegiatan pengumuman, pendistribusian dan komunikasi karya film dimana kegiatan tersebut tergolong pelanggaran Hak Cipta. Dengan kata lain adalah memohon putusan provisi atau putusan sela kepada Pengadilan untuk melakukan penutupan situs web IndoXX1 agar seluruh kegiatannya yang melanggar Hak Cipta karya film terhentikan.

Hukum pidana menganut asas ultimum remedium yaitu hukum pidana hendaklah dijadikan upaya terakhir dalam hal penegakan hukum. Sebenarnya Undang-Undang Hak Cipta turut mengatur mengenai hal tersebut yaitu dalam Pasal 95 ayat (4) Undang-Undang Nomor 28 Tahun 2014 tentang Hak Cipta yang mengatur bahwa selain kasus pembajakan dan selama para pihak yang bersengketa diketahui keberadaannya dan berada di wilayah Negara Kesatuan Republik Indonesia maka harus menempuh jalur mediasi sebagai upaya penyelesaian sengketa sebelum melakukan tuntutan pidana. Ketentuan pidana yang dapat dikenakan terhadap pelaku pelanggaran Hak Cipta adalah ketentuan pidana yang diatur 
dalam Pasal 113 ayat (2) juncto Pasal 113 ayat (3) Undang-Undang Nomor 28 Tahun 2014 tentang Hak Cipta karena pihak situs web IndoXX1 telah melanggar Pasal 9 ayat (1) huruf e, g, dan h Undang-Undang Nomor 28 Tahun 2014 tentang Hak Cipta dimana pihak situs web IndoXX1 mendistribusikan, mengumumkan dan mengkomunikasikan karya film kepada publik melalui situs web IndoXX1 tanpa seizin pencipta atau pemegang Hak Cipta karya film tersebut untuk penggunaan secara komersial. Kemudian pihak situs web IndoXX1 tidak memberikan royalti kepada pencipta atau pemegang Hak Cipta karya film tersebut sehingga pencipta atau pemegang Hak Cipta karya film menderita kerugian. Berdasarkan uraian tersebut, dengan demikian dapat disimpulkan bahwa seluruh upaya untuk melindungi karya film terhadap kegiatan streaming gratis pada situs web IndoXX1 baik itu upaya gugatan keperdataan (gugatan ganti rugi dan penutupan situs web IndoXX1) maupun upaya penuntutan pidana bergantung kepada peran aktif dari pencipta atau pemegang Hak Cipta karya film untuk melaporkan adanya pelanggaran Hak Cipta yang dilakukan oleh situs web IndoXX1.

Peran aktif dari pencipta atau pemegang Hak Cipta karya film sangat dibutuhkan karena tanpa adanya laporan atau pengaduan dari pencipta atau pemegang Hak Cipta karya film atas adanya pelanggaran Hak Cipta yang dilakukan oleh situs web IndoXX1 maka Direktorat Jenderal Kekayaan Intelektual tidak dapat memberikan upaya perlindungan karena yang berlaku dalam Undang-Undang Hak Cipta adalah delik aduan. Sehingga walaupun sudah dilakukan penutupan situs terhadap situs web IndoXX1 pencipta atau pemegang Hak Cipta harus terus waspada untuk memantau dan aktif untuk melaporkan kembali apabila ditemukan pelanggaran Hak Cipta yang dilakukan oleh situs web IndoXX1 karena pihak situs web IndoXX1 mengganti nama domain situs web IndoXX1 secara terus menerus.

\section{KESIMPULAN}

Berdasarkan analisis yang telah dilakukan maka kesimpulan dari penelitian adalah sebagai berikut:

a. Pengaturan Hak Cipta film terhadap kegiatan streaming film gratis pada situs web IndoXX1 dengan menerapkan Pasal 55 ayat (1) Undang-Undang Nomor 28 Tahun 2014 tentang Hak Cipta telah diberikan oleh Direktorat Jenderal Kekayaan Intelektual dengan berkoordinasi bersama Kementerian Komunikasi dan Informatika Republik Indonesia untuk melakukan penutupan situs web IndoXX1 secara keseluruhan atas laporan yang diberikan oleh Motion Picture Association (MPA) kepada Direktorat Jenderal Kekayaan Intelektual. Selain daripada hal tersebut pengaturan Hak Cipta Film terhadap kegiatan streaming film gratis pada situs web IndoXX1 dalam Undang-Undang Hak Cipta diatur bahwa pencipta atau pemegang Hak Cipta dimungkinkan untuk mengajukan gugatan keperdataan sebagaimana dalam Pasal 99 UndangUndang Hak Cipta termasuk memohon putusan sela kepada Pengadilan Niaga untuk melakukan penutupan situs web IndoXX1 agar kegiatan yang melanggar Hak Cipta terhenti dan pencipta atau pemegang Hak Cipta juga dimungkinkan untuk melakukan tuntutan pidana sebagaimana diatur dalam Pasal 113 ayat (2) dan ayat (3) Undang-Undang Hak Cipta. Tetapi ketentuan pidana dan gugatan keperdataan tidak dapat dikenakan kepada pelanggar Hak Cipta apabila tidak diawali dengan adanya laporan dari pencipta atau pemegang Hak Cipta karya film karena Undang-Undang Hak Cipta menganut delik aduan. Delik aduan tersebut menjadi kelemahan dari ketentuan pidana karena diperlukannya kesadaran dari pencipta karya film untuk melaporkan.

b. Seluruh upaya untuk memberikan perlindungan Hak Cipta film terhadap kegiatan streaming film gratis pada situs web IndoXX1 baik itu upaya untuk 
mengajukan gugatan keperdataan yang diatur dalam Pasal 99 Undang-Undang Nomor 28 Tahun 2014 tentang Hak Cipta (gugatan ganti rugi dan memohonkan penutupan situs web IndoXX1) maupun upaya melakukan penuntutan pidana sebagaimana diatur dalam Pasal 113 ayat (2) dan ayat (3) Undang-Undang Hak Cipta sangat bergantung dari kesadaran pencipta atau pemegang Hak Cipta karya film untuk berperan aktif melaporkan pelanggaran Hak Cipta yang dilakukan oleh situs web IndoXX1. Hal tersebut dikarenakan tanpa adanya laporan dari pencipta atau pemegang Hak Cipta maka perlindungan terhadap Hak Cipta film terhadap kegiatan streaming film gratis pada situs web IndoXX1 tidak dapat diberikan oleh Direktorat Jenderal Kekayaan Intelektual karena UndangUndang Hak Cipta menganut delik aduan sehingga laporan mengenai adanya pelanggaran Hak Cipta dari pencipta atau pemegang Hak Cipta karya film menjadi kunci utama untuk melindungi karya film tersebut. Pencipta atau pemegang Hak Cipta karya film harus terus memantau dan aktif melaporkan pelanggaran Hak Cipta yang dilakukan oleh situs web IndoXX1 karena situs tersebut terus berusaha mengganti nama domain mereka agar terhindar dari penutupan situs.

\section{SARAN}

a. Pemerintah harus lebih memberikan perhatian terhadap penerapan UndangUndang Hak Cipta. Sehingga pemerintah dapat mengetahui apakah dalam penerapannya efektif atau tidak. Pengaturan mengenai delik aduan dalam Undang-Undang Nomor 28 Tahun 2014 tentang Hak Cipta dapat dinilai kurang efektif karena membutuhkan kesadaran Pencipta untuk melakukan pengaduan agar mendapat perlindungan. Berdasarkan hal tersebut maka pelu diubah mengenai delik yang berlaku dalam Undang-Undang Nomor 28 Tahun 2014 tentang Hak Cipta yaitu dari yang semula delik aduan menjadi delik biasa. b. Masyarakat Indonesia harus segera menyadari akan pentingnya Hak Cipta demi kemajuan bangsa dan negara Republik Indonesia. Apabila masyarakat sadar akan pentingnya Hak Cipta maka secara perlahan otomatis pengguna situs layanan streaming film gratis akan menurun jumlahnya sehingga menyebabkan penurunan keuntungan ekonomi yang didapat oleh situs web IndoXX1 karena masyarakat pasti beralih kepada penyedia layanan streaming film yang legal seperti Netflix dan Iflix. Dengan begitu pasti situs web IndoXX1 dan situs penyedia layanan streaming film gratis ilegal lainnya akan berhenti melakukan pelanggaran Hak Cipta karena situs web mereka kurang diminati.

\section{DAFTAR PUSTAKA}

Marzuki, Peter Mahmud, Penelitian Hukum, Jakarta: Kencana Prenada Media Group, 2009.

Soekanto, Soerjono, Pengantar Penelitian Hukum, Jakarta: UI-Press, 1986. dan Sri Mamudji, Penelitian Hukum Normatif Suatu Tinjauan Singkat, Jakarta : PT Raja Grafindo Persada, 2009.

Undang-Undang Nomor 33 Tahun 2009 tentang Perfilman. LN No. 141 Tahun 2009. TLN No. 5060 Tahun 2009.

Undang-Undang Nomor 28 Tahun 2014 tentang Hak Cipta. LN No. 266 Tahun 2014. TLN No. 5599 Tahun 2014.

Undang-Undang Nomor 19 Tahun 2016 tentang Perubahan Atas UndangUndang Nomor 11 Tahun 2008 tentang Informasi dan Transaksi Elektronik. LN No. 251 Tahun 2016. TLN No. 5952 Tahun 2016.

Peraturan Bersama Menteri Hukum dan Hak Asasi Manusia Republik Indonesia dan Menteri Komunikasi dan Informatika Republik Indonesia Nomor 14 Tahun 2015 dan Nomor 26 Tahun 2015 tentang Pelaksanaan Penutupan Konten dan/atau Hak Akses Pengguna 
Jurnal Ilmu Sosial dan Pendidikan

Vol. 5. No. 2 Maret 2021

http://ejournal.mandalanursa.org/index.php/JISIP/index

Terakreditasi Peringkat 5 (No. SK: 85/M/KPT/2020)

p-ISSN: 2598-9944 e-ISSN: 2656-6753

Pelanggaran Hak Cipta dan/atau Hak

Terkait dalam Sistem

Elektronik. 